\title{
Intervenção manual ao parto em suínos: estudo comparativo do desempenho reprodutivo,longevidade e produção de leite*
}

\author{
ANA PAULA GONÇALVES MELLAGI \\ Ivo Wentz (Orientador - UFRGS) \\ Fernando Pandolfo Bortolozzo (Co-orientador - UFRGS) \\ Mari Lourdes Bernardi (Co-orientadora - UFRGS)
}

Banca: Guilherme Borchardt Neto (UNICRUZ), Paulo Roberto Silveira (EMBRAPA), Rui Fernando Félix Lopes (UFRGS)

\begin{abstract}
O experimento 1 caracterizou as fêmeas com intervenção manual no parto, além de avaliar os efeitos que podem ocorrer na sua vida reprodutiva ao longo de 1 ano. Foram coletados dados do parto de 4.121 fêmeas, informações anteriores ao parto e registrados os motivos e momentos de remoção. Os animais foram divididos em grupo Controle ( $\mathrm{n}=3.271)$ e Intervenção (n=850). O percentual de fêmeas submetidas à intervenção manual no parto foi de 20,6\%. Houve aumento na distribuição de intervenções na ordem de parto (OP) acima de 5 e no verão $(\mathrm{P}<0,05)$. A distribuição não diferiu entre as classes de tamanho da leitegada (P>0,05). Foi verificada diferença na média de OP (3,6 e 4,7), duração do parto (208,3 e 224,6 min), leitões nascidos vivos $(11,9$ e 11,6), natimortos $(0,3$ e 0,6$)$ e no percentual de fêmeas com natimortos $(28,6$ e 38,8\%) nos grupos Controle e Intervenção, respectivamente. A remoção geral foi maior no grupo Intervenção $(\mathrm{P}=0,001)$ e antes da IA por motivos não reprodutivos $(\mathrm{P}<0,001)$. No desempenho subsequente, houve diminuição da taxa de parto ajustada e do tamanho da leitegada subsequente $(\mathrm{P}<0,05)$. O experimento 2 visou avaliar o parto com e sem intervenção manual, estimar o desempenho lactacional e avaliar as causas de remoção e o desempenho reprodutivo subsequente destas fêmeas. Foram comparadas 319 fêmeas, divididas em dois grupos: Controle $(n=222)$ e Intervenção $(n=97)$. Todas as fêmeas com intervenção receberam uma dose de antimicrobiano. Foram coletados dados reprodutivos referentes ao parto, o peso dos leitões no dia 1 (D1), dia 14 (D14) e no dia 21 (D21), e a produção de leite no $14^{\circ}$ dia de lactação, pela técnica da pesagem-mamada-pesagem. Foram analisadas as informações do desempenho subsequente e das causas de remoção das matrizes. Houve diferença $(\mathrm{P}<0,01)$ para as variáveis ordem de parto $(3,2$ e 4,0), leitões nascidos totais $(12,2$ e 11,2) e nascidos vivos $(11,4$ e 10,2) e número de natimortos $(0,5$ e 1,0) entre os grupo Controle e Intervenção, respectivamente. A produção de leite, aos 14 dias, não diferiu, porém o peso dos leitões aos 21 dias tende a ser menor $(\mathrm{P}=0,09)$ no grupo Intervenção. Houve diferença $(\mathrm{P}<0,05)$ nas remoções gerais $(18,9$ e $32,0 \%)$ e antes da IA (8,6 e 20,6\%), sendo destas por motivos não reprodutivos (8,6 e 19,6\%) entre os grupos Controle e Intervenção, respectivamente. Os resultados conjuntos mostram que a intervenção manual ao parto é efetuada com maior freqüência no verão, em fêmeas de maior ordem de parto e com menor tamanho da leitegada. Nestas fêmeas, o parto é mais prolongado e o número de natimortos é maior. A produção de leite, aos 14 dias, não é prejudicada, porém o peso dos leitões aos 21 dias tende a ser menor nas matrizes submetidas à palpação genital. As remoções são maiores nestas fêmeas, sendo realizadas antes da IA e por motivos não reprodutivos. As fêmeas submetidas à intervenção ao parto têm o desempenho reprodutivo subsequente reduzido.
\end{abstract}

Descritores: Intervenção manual ao parto, estação, reprodução, produção de leite, remoção, suínos.

*Dissertação de Mestrado n 457 (Especialidade: Fisiopatologia da Reprodução). 59f. Programa de Pós-Graduação em Ciências Veterinárias [www.ufrgs.br/ ppgcv], Faculdade de Veterinária, Universidade Federal do Rio Grande do Sul (UFRGS), Porto Alegre, RS. CORRESPONDÊNCIA: Ivo Wentz [ivowentz@ufrgs.br]. 


\title{
Manual intervention at parturition in swine: comparative study of reproductive performance, longevity and milk production**
}

ANA PAULA GONÇALVES MELLAGI

\author{
Ivo Wentz (Advisor - UFRGS) \\ Fernando Pandolfo Bortolozzo (Co-advisor - UFRGS) \\ Mari Lourdes Bernardi (Co-advisor - UFRGS)
}

Committee: Guilherme Borchardt Neto (UNICRUZ), Paulo Roberto Silveira (EMBRAPA), Rui Fernando Félix Lopes (UFRGS)

Experiment 1 characterized the females with manual intervention at the parturition, and evaluated the effect that can occur in their reproductive life, during one year. Data about the farrowing were collected from 4,121 females; information previous at parturition and the reasons and moments of removal were recorded. The animals were allocated in Control $(n=3,271)$ and Intervention $(n=850)$ groups. The percentage of females submitted to the manual intervention at the parturition was of $20.6 \%$. There was an increase in the proportions of interventions in the order of parturition (OP) above 5. Moreover, this growth took place mainly in summer $(\mathrm{P}<0.05)$. Differences in the OP average (3.6 and 4.7), duration of farrowing (208.3 and $224.6 \mathrm{~min}$ ), born alive piglets (11.9 and 11.6), stillborns (0.3 and 0.6) and in the percentage of females with stillborns (28.6 and $38.8 \%$ ) were verified, in Control and Intervention group, respectively. Culling rate was higher in the Intervention group $(\mathrm{P}=0.001)$ and before the insemination, due to non-reproductive reasons $(\mathrm{P}<0.001)$. On the subsequent performance, there was reduction of the adjusted farrowing rate and in litter size $(\mathrm{P}<0.05)$. Experiment 2 sought to evaluate parturition with and without manual intervention, estimate the milk production and to evaluate the culling causes and the subsequent reproductive performance of these females. The females $(n=319)$ were allocated in two groups and compared: Control ( $\mathrm{n}=222)$ and Intervention $(n=97)$. All the Intervention group females received a dose of antimicrobials. Reproductive data were collected at parturition, as well as pigs weight in day 1 (D1), day 14 (D14) and in day 21 (D21), and milk production on $14^{\text {th }}$ day of lactation, by the weigh-suckle-weigh technique. The information of the subsequent performance and the sow's removal causes were analyzed. There were differences for OP (3.2 and 4.0), total pigs born (12.2 and 11.2) and born alive piglets (11.4 and 10.2) and stillborn number (0.5 and 1.0) variables between Control and Intervention groups, respectively. Milk production, on $14^{\text {th }}$ day, did not differ, however the piglets weight on 21 days tended to be lower $(\mathrm{P}=0.09)$ in the Intervention group. There was difference in the culling rate (18.9 and $32.0 \%$ ) and before the insemination (8.6 and 20.6\%), due to non-reproductive reasons (8.6 and $19.6 \%)$ between the Control and Intervention group, respectively. The set results show that the manual intervention at parturition is performed mainly in summer, in older females and with small litter size. In these females, the parturition is longer and the stillborn is higher. Even though the milk production is not affected, the piglets weight on 21 days tends to be lower in the sows submitted to the genital palpation. The culling rate is higher in these females, before the insemination and for non-reproductive reasons. Females submitted to intervention at the parturition have subsequent reproductive performance reduced.

Key words: Manual intervention at farrowing, season, reproduction, milk production, removal, swine.

Presented: 26 February 2007

**Master's Thesis \#457 (Field: Theriogenology). 59p. Graduated Program in Veterinary Sciences [www.ufrgs.br/ppgcv], Faculdade de Veterinária,Universidade Federal do Rio Grande do Sul (UFRGS), Porto Alegre/Brazil. CORRESPONDENCE: Ivo Wentz [ivowentz@ufrgs.br]. 